\title{
Pengunaan Komposisi Media Tanam Arang Sekam dan Pupuk Padat Kotoran Sapi Terhadap Pertumbuhan Tanaman Cabe merah (Capsicum annuum L)
}

\author{
Nehru $^{1}$, Muhammad Nur ${ }^{2}$, Bakhtiar ${ }^{3}$, Fahruddin ${ }^{4}$ \\ 1,3,4, Dosen Program Studi Pendidikan Biologi STKIP Bima \\ 2Mahasiswa Program Studi Pendidikan Biologi STKIP Bima \\ (E-mail: mpdnehru@gmail.com)
}

\begin{abstract}
Abstrak
Penelitian bertujuan untuk mengetahui pengaruh penggunaan berbagai media tanam hidroponik (pasir, arang dan abu gosok) terhadap pertumbuhan tanaman cabe merah besar (Capsicum annum varietes longum). Jenis penelitian ini adalah eksperimen menggunakan Rancangan Acak Lengkap (RAL) yang terdiri dari 4 macam perlakuan dengan 1 perlakuan sebagai control dengan masing-masing 4 kali pengulangan sehingga akan di peroleh 16 percobaan tiap pot perlakuan ditanam 1 pohon cabai merah besar. Hasil penelitian ini menunjukkan bahwa Penggunaan media tanam hidroponik dapat mempengaruhi pertumbuhan cabai merah besar (Capsicum annum, varietas longum) baik itu pada tinggi tanaman, panjang daun dan jumlah daun. Media tanam hidroponik yang paling bagus adalah media tanam dengan pasir. Hal ini dapat dilihat pada pengukuran tiap-tiap parameter penelitian sebagai beriku : Tinggi tanaman paling tinggi dengan rata-rata 20,37 cm (40 HSPT), dengan jumlah daun yang paling banyak dengan rata-rata 9,25 lembar (40 HSPT), dan panjang daun yang paling panjang dengan rata-rata $6,87 \mathrm{~cm}(H S P T)$.
\end{abstract}

Kata Kunci: Media Arang Sekam, Kotoran Sapi, Pertumbuhan tanaman cabai

\section{PENDAHULUAN}

Kebutuhan masyarakat akan sayursayuran terus meningkat sejalan dengan pertambahan penduduk. Kesadaran akan gizi semakin tinggi, peningkatan pendapatan semakin bertambah, sedangkan peningkatan produktifitas tersebut disebabkan antara lain rendahnya mutu benih, gangguan hama dan penyakit, keadaan alam yang tidak menguntungkan seperti kekeringan, suhu tinggi dan hujan lebat. Disamping itu juga kualitas produksi sayuran yang baik sangat tergantung pada petani dan pengusaha pertanian karena tanaman sayur-sayuran yang dibudidayakan membutuhkan perawatan yang baik.
Salah satu tanaman yang dibudidayakan di Indonesia adalah cabai, tanaman cabai sendiri sudah dikenal oleh masyarakat dan hampir dibutuhkan oleh lapisan masyarakat yaitu sebagai bumbu dapur, pemberi rasa pada masakan dan makanan. Oleh karena itu tanaman ini identik rasanya yang pedas, sebagai tanaman yang dibudidayakan cabai dapat hidup dan tumbuh dengan subur pada areal sawah maupun musim hujan.

Tanaman cabai juga mempunyai peranan penting bagi kehidupan masyarakat, selain dapat meningkatkan pendapatan masyarakat, cabai juga memiliki banyak kandungan gizi 
yang masing-masing jenisnya akan berlainan seperti, kalori, protein, lemak, karbohidrat, kalium, vitamin dan air (Setiadi, 2000).

Kebutuhan masyarakat terhadap cabai terus mengalami peningkatan, maka perlu dilakukan upaya budidaya cabai merah secara maksimal dengan menggunakan pupuk organik. Marsono et al. (2001), pemberian bahan organik dapat memperbaiki struktur tanah yang padat menjadi gembur dengan menyediakan ruang untuk udara dan air. Ruang yang berisi udara akan mendukung pertumbuhan bakteri aerob yang berada diakar, sedangkan air yang tersimpan di dalam ruang tanah menjadi persediaan bagi tanaman

Bahan organik mempunyai peranan penting dalam mempertahankan kesuburan tanah. Beberapa bahan organik yang dapat digunakan diantaranya arang sekam padi dan pupuk kotoran sapi. Arang sekam merupakan salah satu campuran media tanam yang dapat mengikat air dan merupakan bahan unsur hara alami yang dapat menyuburkan tanaman karena sifatnya yang remah dan strukturnya mudah menyimpan oksigen. Arang sekam mengandung $\mathrm{N} \mathrm{0,32 \% ,} \mathrm{P2O} \mathrm{15 \% ,} \mathrm{K2O} \mathrm{31 \% ,}$ Ca 0,95\%, dan Fe 180 ppm, Mn 80 ppm, Zn 14,1 ppm dan pH 6,8. Arang sekam merupakan hasil pembakaran tak sempurna dari sekam padi. Arang sekam mempunyai sifat yang mudah mengikat air, tidak mudah menggumpal, harganya relatif murah, bahannya mudah didapat, ringan, steril dan berguna untuk meningkatkan kapasitas porositas tanah Prihmantoro dalam Susilawati, 2019).

Media tanam yang campur bahan organik dari kotoran sapi selain dapat meningkatkan hasil produksi tanaman. Pupuk kandang kotoran sapi banyak mengandung air, kandungan air yang tinggi memungkinkan kelarutan hara lebih baik dan media tersebut dapat mensuplai hara. Menurut Mulyani dalam Susilawati (2019), komposisi unsur hara pada pupuk kandang kotoran sapi pada wujud bahan padat yaitu mengandung $85 \% \mathrm{H} 2 \mathrm{O}$, $0,40 \% \quad \mathrm{~N}, \quad 0,20 \%$ P2O5, dan 0,10 K2O. sedangkan pada wujud bahan cair mengandung $92 \% \mathrm{H} 2 \mathrm{O}, 1,00 \% \quad \mathrm{~N}, 0,20 \%$ $\mathrm{P} 2 \mathrm{O} 5$, dan 1,35\% K2O.

Berdasarkan latar belakang di atas penelitian ingin melakukan penelitian yang berkaitan dengan media sebagai tempat tumbuh tanaman dengan judul pengaruh penggunaan berbagai media tanam hidroponik (pasir, arang dan abu gosok) terhadap tanaman cabai merah besar (capsicum annum varietes longum)

\section{METODE}

\section{Rancangan Penelitian}

Dalam penelitian ini menggunakan Rancangan Acak Lengkap (RAL) yang terdiri dari 4 macam perlakuan dengan 1 perlakuan 
sebagai control dengan masing-masing 4 kali pengulangan sehingga akan diperoleh 16 percobaan tiap pot perlakuan ditanam 1 pohon cabai merah besar. Perlakuan tersebut adalah sebagai berikut :

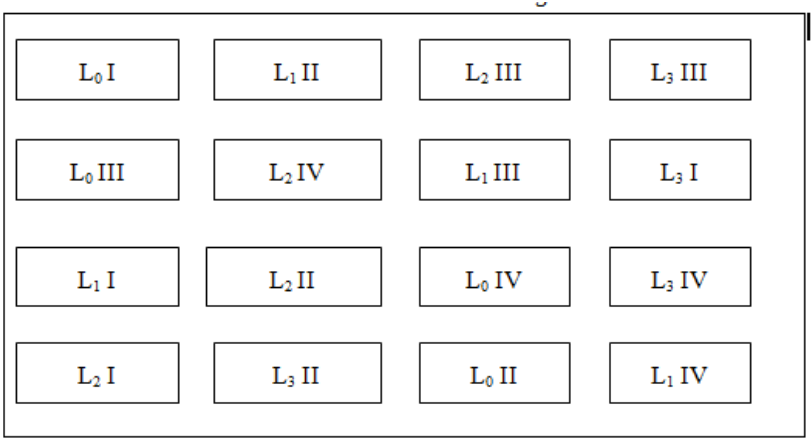

Gambar 1. Rancangan Penelitian

\section{Keterangan:}

L0: perlakuan dengan menggunakan media tanah sebagai kontrol

L1: Perlakuan dengan menggunakan media tanam abu gosok

L2: Perlakuan dengan menggunakan media tanam arang

L3: Perlakuan dengan menggunakan media tanam pasir

I, II, III, IV : pengulangan

\section{Alat dan Bahan}

Alat dan bahan yang diperlukan dalam penelitian ini yaitu Cangkul, Kaleng besar, Sendok, Sekop, Ember, Penggaris, Benang, Hand sprayer, Bibit tanaman cabai, Pasir, Arang Abu gosok, pot, kertas karton, larutan nutrient, Pupuk.

\section{Parameter Pengamatan}

Pengamatan indikator pertumbuhan yang diamati meliputi: Pertumbuhan tanaman cabe merah yang diamati terdiri dari tiga parameter yaitu tinggi tanaman ju,mlah daun dan panjang daun.

\section{Prosedur Penelitian}

Untuk memperoleh data, maka pada penelitian ini ditempuh langkah-langkah sebagai berikut :

1. Persiapan benih

Biji tanaman cabai merah besar yang akan disemaikan dibeli di toko pertanian. Biji tersebut dijemur selama 5 jam dan dimasukan dalam ember yang berisi air, hal ini dilakukan untuk menyeleksi cabai merah tersebut lalu biji diaduk, jika terlihat biji yang mengambang berarti biji itu kurang baik, apabila biji tenggelam maka biji itu bagus dan cocok dijadikan benih dan bisa langsung disemaikan. Tanah yang dijadikan lahan persemaian merupakan campuran pasir dan tanah. Setelah bibit berumur 40 hari baru dipindahkan ke dalam pot media tanam penelitian

2. Persiapan media

Media tanam yang digunakan untuk penelitian adalah abu gosok, arang, dan pasir. Ketiga media tanam tersebut disterilkan terlebih dahulu dengan cara dipanaskan hingga mencapai titik didih kurang lebih $100^{\circ} \mathrm{C}$. Setelah media tanam siap yaitu pot kecil yang tingginya kurang lebih $15 \mathrm{~cm}$ diisi pasir, arang, abu gosok kira-kira setinggi $9 \mathrm{~cm}$ dan bibit yang akan dipindahkan akarnya terlebih dahulu dibersihkan baru bibit tersebut dipindahkan pada media tanam penelitian.

3. Pemberian pupuk dan garam-garam mineral 
Untuk pupuk atau garam-garam mineral yang diberikan pada tanaman menggunakan pupuk organic Green Tonic yang menggunakan unsur-unsur makro dan mikro. Pupuk organic ini dicampur dengan air dengan perbandingan $3 \mathrm{cc}$ untuk pupuk organik dengan 1 liter air. Setelah itu disiramkan secara langsung dengan selang waktu 1 minggu 2 kali dan penyiraman dengan air biasa 2 kali sehari yaitu pagi dan sore. Setelah melalui langkahlangkah di atas maka dilakukan pengumpulan data

\section{Analisis Data}

Untuk mengetahui adanya pengaruh yang nyata dari penggunaan media hidroponik terhadap tanaman cabai merah dilakukan analisis data menggunakan Analisis of Varience (ANOVA) dengan taraf signifikan 5\%, Apabila $\mathrm{F}$ hitung lebih besar dari $\mathrm{F}$ tabel berarti ada beda nyata diantara perlakuan dan sebaliknya jika terdapat perbedaan yang nyata, maka dilanjutkan dengan uji BNT (Beda Nyata Terkecil), pada taraf signifikan 5\% (Rahmawati, dkk, 2019).

\section{HASIL DAN PEMBAHASAN}

Pertumbuhan merupakan suatu proses perubahan ukuran organ-organ tanaman akibat adanya penambahan ukuran sel yang mencerminkan proses pertumbuhan (Azmin dkk, 2015). Keberhasilan pertumbuhan tanaman dapat ditinjau dari berbagai aspek, salah satunya adalah pertumbuhan tanaman yang dapat diamati melalui indicator pertumbuhan tanama yaitu:

\section{Pertumbuhan Tinggi}

Pengamatan tinggi tanaman 40 HSPT dilakukan dengan cara mengukur tinggi tanaman dari pangkal batang di atas permukaan media tanam sampai ke pucuk daun. Berdasarkan hasil pengamatan tinggi tanaman tersebut dapat dilihat pada tabel 1:

Tabel 1 Hasil Pengamatan Tinggi Tanaman 40 HSPT

\begin{tabular}{|c|c|c|c|c|c|}
\hline \multirow{2}{*}{ Ulangan } & \multicolumn{4}{|c|}{ Perlakuan } & \multirow{2}{*}{ TotalT } \\
\cline { 2 - 5 } & $\mathrm{L}_{0}$ & $\mathrm{~L}_{1}$ & $\mathrm{~L}_{2}$ & $\mathrm{~L}_{3}$ & \\
\hline I & 13.0 & 15.5 & 10.5 & 20.0 & 67.0 \\
II & 12.5 & 19.5 & 16.0 & 18.5 & 66.5 \\
III & 11.5 & 17.3 & 20.0 & 20.5 & 69.5 \\
IV & 13.5 & 14.0 & 20.0 & 22.5 & 70.5 \\
\hline Total & 50.5 & 66.3 & 66.5 & 81.5 & 273.5 \\
\hline Rata-Rata & 12.62 & 16.57 & 16.62 & 20.37 & 68.37 \\
\hline
\end{tabular}

Dari data di atas terdapat pada tabel 1 menunjukan bahwa rata-rata tinggi tanaman pada masing-masing perlakuan menunjukan angka yang tertinggi dari perlakuan $: \mathrm{L}_{3}=$ $20.37 \mathrm{~cm}, \mathrm{~L}_{2}=16.62 \mathrm{~cm}, \mathrm{~L}_{1}=16.57 \mathrm{~cm}$, dan $\mathrm{L}_{0}=12.62 \mathrm{~cm}$.

Hasil analisis ragam Tinggi Tanaman cabai merah besar (capsicum annum varietas longum), pada umur 40 hari setelah pindah tanam (HSPT) dapat disajikan pada tabel 2 berikut: 
Tabel 2 Hasil analisis ragam Tinggi Tanaman Cabai 40 HSPT

\begin{tabular}{|c|c|c|c|c|c|}
\hline $\begin{array}{c}\text { Sumber } \\
\text { keterangan }\end{array}$ & $\begin{array}{c}\text { Derajat } \\
\text { bebas }\end{array}$ & $\begin{array}{c}\text { Jumlah } \\
\text { kuadrat }\end{array}$ & $\begin{array}{c}\text { Jumlah } \\
\text { tengah }\end{array}$ & F- Hitung & F-tabel \\
\hline Perlakuan & 3 & 4374.161 & 1093.54 & 4.41 & 3,24 \\
\hline Error & 15 & 3712.26 & 247.48 & - & - \\
\hline Total & 18 & 661.90 & & - & - \\
\hline
\end{tabular}

Ket: Berdasarkan perhitungan analisis data keragaman tinggi tanaman cabai besar setelah 40 HSPT menunjukan $\mathrm{F}_{\text {hit }}>\mathrm{F}_{\text {tab }}$ dan di lanjutkan dengan uji BNT 5\% berbeda nyata atau tidak

Perhitungan Beda Nyata Terkecil (BNT)

$$
\begin{aligned}
\text { BNT 5\% } & =t .5 \%(\text { db.error }) x \sqrt{\frac{2 . K T E}{r}} \\
& =2,120 x \sqrt{\frac{2.3712 .26}{4}} \\
& =2,120 x \sqrt{\frac{7424.52}{4}} \\
& =2,120 x \sqrt{1,37} \\
& =2,120 x 1,17 \\
& =2,48
\end{aligned}
$$

$B N T(0,05)=2,48$

Tabel 3. Perlakuan dan Nilai Tengah

\begin{tabular}{|c|c|c|c|c|}
\hline \multirow{2}{*}{ Perlakuan dan } & \multicolumn{4}{|c|}{ Perlakuan dan Nilai Tengah } \\
\cline { 2 - 5 } Nilai Tengah & $\mathrm{L}_{0}$ & $\mathrm{~L}_{1}$ & $\mathrm{~L}_{2}$ & $\mathrm{~L}_{3}$ \\
\hline $\mathrm{L}_{0} 12,9$ & - & 3,6 & $6,0^{*}$ & $7,0^{*}$ \\
$\mathrm{~L}_{1} 16,5$ & - & - & 2,4 & $4,0^{*}$ \\
$\mathrm{~L}_{2} 18,9$ & - & - & - & 1,6 \\
$\mathrm{~L}_{3} 20,5$ & - & - & - & - \\
\hline
\end{tabular}

Ket: Berdasarkan hasil uji BNT dan perhitungan nilai tengah maka dapat diketahui bahwa perlakuan $\mathrm{L}_{3}$ berbeda nyata dengan perlakuan $\mathrm{L}_{2}, \mathrm{~L}_{1}, \mathrm{~L}_{0}$. Perlakuan $\mathrm{L}_{2}$ berbeda nyata dengan $\mathrm{L}_{1}$, dan $\mathrm{L}_{0}$ dan perlakuan $\mathrm{L}_{1}$, berbeda nyata dengan $\mathrm{L}_{0}$.

Penggunaan media tanam yang berbeda ternyata memberi pengaruh yang berbeda juga pada pertumbuhan tanaman perlakuan dengan menggunakan media tanam hidroponik pasir ternyata memberikan pertumbuhan tinggi tanaman yang paling tinggi dibandingkan dengan perlakuan yang lainnya, dari pra penelitian sampai tanaman berumur 40 hari setelah pindah tanam (HSPT) dengan rata-rata perlakuan dengan menggunakan media tanam tanah $\left(\mathrm{A}_{0}\right)$ dengan rata-rata $12,62 \mathrm{~cm}$, perlakuan dengan menggunakan media tanam abu gosok $\left(A_{1}\right)$ dengan rata-rata $16,57 \mathrm{~cm}$, perlakuan dengan menggunakan media tanam arang $\left(\mathrm{A}_{2}\right)$ dengan rata-rata $16,62 \mathrm{~cm}$, dan perlakuan dengan menggunakan media tanam pasir $\left(A_{3}\right)$ dengan rata-rata $20,37 \mathrm{~cm}$, dimana $\mathrm{F}_{\text {hitung }}>\mathrm{F}_{\text {tabel }}(4,41>3,24)$.

Hal ini sesuai dengan pendapat Nichollis. R (1993 ), menyatakan sejak tahun 30-an pasir merupakan pilihan yang sering dipakai karena sifatnya steril, dapat mempertahankan kelembaban yang baik dalam unit terbesar maupun terkecil. Disamping itu juga dengan menggunakan media tanam pasir memberi kemudahan dalam proses penyaluran nutrisi dan garam-garam mineral dengan cara yang paling sederhana adalah menaburkan garamgaram pupuk pada permukaan pasir lalu menuangkan air diatasnya, air akan melarutkan garam dan pasir akan menyerap air dan akarakar akan menyerap zat-zat makanan tersebut 


\section{Pertumbuhan Jumlah daun}

Pengamatan pada jumlah daun tanaman berumur 40 HSPT, dilakukan dengan cara menghitung jumlah daun yang terbentuk. Berdasarkan hasil pengamatan jumlah daun penelitian dan 40 HSPT (lembar) dapat dilihat pada tabel 4 .

Tabel 4 Hasil Pengamatan jumlah daun Tanaman 40 HSPT

\begin{tabular}{|c|c|c|c|c|c|}
\hline \multirow{2}{*}{ Ulangan } & \multicolumn{4}{|c|}{ Perlakuan } & \multirow{2}{*}{ Total/ } \\
\hline & $\mathrm{L}_{0}$ & $\mathrm{~L}_{1}$ & $\mathrm{~L}_{2}$ & $\mathrm{~L}_{3}$ & \\
\hline I & 7 & 7 & 9 & 9 & 32 \\
\hline II & 6 & 8 & 8 & 9 & 31 \\
\hline III & 5 & 7 & 8 & 9 & 29 \\
\hline IV & 6 & 6 & 9 & 10 & 31 \\
\hline Total & 24 & 28 & 34 & 37 & 123 \\
\hline Rata-Rata & 6 & 7 & 8.5 & 9.25 & 30.75 \\
\hline
\end{tabular}

Dari data yang terdapat pada tabel 4 menunjukan bahwa rata-rata jumlah daun pada masing-masing perlakuan menunjukan angka tertinggi pada perlakuan : $\mathrm{L}_{3}=9.25$ lembar, $\mathrm{L}_{2}$ $=8.5$ lembar, $\mathrm{L}_{1}=7$ lembar, $\mathrm{L}_{0}=6$ lem

Hasil analisis ragam jumlah Daun cabai merah besar (capsicum annum varietas longum), pada umur 40 hari setelah pindah tanam (HSPT) dapat disajikan pada tabel 5 berikut:

Tabel 5 Hasil analisis ragam jumlah Daun Tanaman Cabai Besar 40 HSPT

\begin{tabular}{|c|c|c|c|c|c|}
\hline $\begin{array}{c}\text { Sumber } \\
\text { keterangan }\end{array}$ & $\begin{array}{c}\text { Derajat } \\
\text { bebas }\end{array}$ & $\begin{array}{c}\text { Jumlah } \\
\text { kuadrat }\end{array}$ & $\begin{array}{c}\text { Jumlah } \\
\text { tengah }\end{array}$ & F- Hitung & F - tabel \\
\hline Perlakuan & 3 & 648.69 & 216.23 & 5.26 & 3,24 \\
\hline Error & 15 & 617.25 & 41.15 & - & - \\
\hline Total & 18 & 31.44 & - & - & - \\
\hline
\end{tabular}

Ket : Berdasarkan perhitungan analisis data keragaman jumlah daun tanaman cabai besar setelah 40 HSPT menunjukan $\mathrm{F}_{\text {hit }}>$
$\mathrm{F}_{\text {tab }}$ dan di lanjutkan dengan uju BNT 5\% berbeda nyata atau tidak

Perhitungan Beda Nyata Terkecil (BNT)

BNT $5 \%=t .5 \%($ db.error $) x \sqrt{\frac{2 . K T E}{r}}$

$=2,120 x \sqrt{\frac{2.617 .25}{4}}$

$=2,120 x \sqrt{\frac{1,46}{4}}$

$=2,120 x \sqrt{0,29}$

$=2,120 \times 0,53$

$=1,12$

$\operatorname{BNT}(0,05)=1,12$

Tabel 6 Perlakuan Nilai Tengah

\begin{tabular}{|c|c|c|c|c|}
\hline \multirow{2}{*}{$\begin{array}{c}\text { Perlakuan dan } \\
\text { Nilai Tengah }\end{array}$} & \multicolumn{4}{|c|}{ Perlakuan dan Nilai Tengah } \\
\cline { 2 - 5 } & $\mathrm{L}_{0}$ & $\mathrm{~L}_{1}$ & $\mathrm{~L}_{2}$ & $\mathrm{~L}_{3}$ \\
\hline $\mathrm{L}_{0} 5,8$ & - & 1,4 & $3,0^{*}$ & $3,8^{*}$ \\
$\mathrm{~L}_{1} 7,2$ & - & - & 1,6 & $2,4^{*}$ \\
$\mathrm{~L}_{2} 8,0$ & - & - & - & 0,8 \\
$\mathrm{~L}_{3} 9,6$ & - & - & - & - \\
\hline
\end{tabular}

Ket: Berdasarkan hasil uji BNT dan perhitungan nilai tengah maka dapat diketahui bahwa perlakuan $\mathrm{L}_{3}$ berbeda nyata dengan perlakuan $\mathrm{L}_{2}, \mathrm{~L}_{1}, \mathrm{~L}_{0}$. Perlakuan $\mathrm{L}_{2}$ berbeda nyata dengan $\mathrm{L}_{1}$, dan $\mathrm{L}_{0}$ dan perlakuan $\mathrm{L}_{1}$, berbeda nyata dengan $\mathrm{L}_{0}$

Begitu juga halnya yang terjadi pada pertumbuhan jumlah daun, perlakuan dengan menggunakan media tanam hidroponik pasir tetap menunjukan pertumbuhan jumlah daun yang paling baik dari perlakuan yang lainnya, dari pra penelitian sampai tanaman berumur 40 hari setelah pindah tanam (HSPT) dengan ratarata : untuk perlakuan dengan menggunakan media tanam tanah $\left(\mathrm{A}_{0}\right)$ jumlah daun dengan 
rata-rata 6 lembar, perlakuan dengan menggunakan media tanam abu gosok $\left(\mathrm{A}_{1}\right)$ jumlah daun dengan rata-rata 7 lembar, perlakuan dengan menggunakan media tanam arang $\left(A_{2}\right)$ jumlah daun dengan rata-rata 8 lembar, dan perlakuan dengan menggunakan media tanam pasir $\left(A_{3}\right)$ jumlah daun dengan rata-rata 9,25 lembar, dimana $F_{\text {hitung }}>F_{\text {tabel }}$ $(5,26>3,24)$.

Hal ini sejalan dengan pernyataan Iqbal (2008), bahwa pupuk kandang sapi mengandung hara $1,7 \% \mathrm{~N}, 0,9 \% \mathrm{P} 2 \mathrm{O} 5,0,3 \%$ K2O. Menurut Munawar (2001) perkembangan dan pertambahan tinggi sangat dipengaruhi oleh kelancaran penyerapan hara yang langsung diangkut dan di olah dalam proses fotosintesis. Hal ini diperkuat oleh Firmanto (2011) yang mengemukakan bahwa $\mathrm{N}$ sangat diperlukan oleh tanaman pertumbuhan vegetaif. Unsur nitrogen digunakan sebagai penyusun utama klorofil dan protein tanaman, selain itu, nitrogen juga memiliki peran pada saat tanaman mengalami proses pertumbuhan vegetatif. Disamping itu juga dengan menggunakan media tanam pasir memberi kemudahan dalam proses penyaluran nutrisi dan garam-garam mineral dengan cara yang paling sederhana adalah menaburkan garam-garam pupuk pada permukaan pasir lalu menuangkan air diatasnya, air akan melarutkan garam dan pasir akan menyerap air dan akarakar akan menyerap zat-zat makanan tersebut

\section{Pertumbuhan Panjang daun}

Pengamatan panjang daun 40 HSPT $(\mathrm{cm})$ dilakukan dengan cara mengukur daun dari pangkal sampai ke ujung daun. Berdasarkan hasil pengamatan panjang daun tanaman berumur 40 HSPT $(\mathrm{cm})$ dapat dilihat pada tabel 7.

Tabel 7 Hasil Pengamatan Panjang daun Tanaman 40 HSPT

\begin{tabular}{|c|c|c|c|c|c|}
\hline \multirow{2}{*}{ Ulangan } & \multicolumn{4}{|c|}{ Perlakuan } & \multirow{2}{*}{ Total/T } \\
\hline & $\mathrm{L}_{0}$ & $\mathrm{~L}_{1}$ & $\mathrm{~L}_{2}$ & $\mathrm{~L}_{3}$ & \\
\hline I & 4.5 & 6.5 & 6.5 & 7.0 & 24.5 \\
\hline II & 3.2 & 6.5 & 6.5 & 6.5 & 22.7 \\
\hline III & 4.5 & 7.5 & 6.2 & 6.5 & 23.7 \\
\hline IV & 4.5 & 5.7 & 6.3 & 7.5 & 24.0 \\
\hline Total & 16.7 & 25.5 & 26.2 & 27.5 & 94.9 \\
\hline Rata-Rata & 4.17 & 6.37 & 6.55 & 6.87 & 23.72 \\
\hline
\end{tabular}

Dari data yang terdapat pada tabel 7 menunjukan bahwa rata-rata panjang daun pada masing-masing perlakuan menunjukan angka tertinggi pada perlakuan : $\mathrm{L}_{3}=6.87 \mathrm{~cm}$, $\mathrm{L}_{2}=6.55 \mathrm{~cm}, \mathrm{~L}_{1}=6.37 \mathrm{~cm}, \mathrm{~L}_{0}=4.17 \mathrm{~cm}$

Hasil analisis ragam Panjang Daun cabai merah besar (capsicum annum varietas longum), pada umur 40 hari setelah pindah tanam (HSPT) dapat disajikan pada tabel 8 berikut:

Tabel 8 Hasil analisis ragam Panjang Daun Tanaman Cabai Besar 40 HSPT

\begin{tabular}{|c|c|c|c|c|c|}
\hline $\begin{array}{c}\text { Sumber } \\
\text { keterangan }\end{array}$ & $\begin{array}{c}\text { Derajat } \\
\text { bebas }\end{array}$ & $\begin{array}{c}\text { Jumlah } \\
\text { kuadrat }\end{array}$ & $\begin{array}{c}\text { Jumlah } \\
\text { tengah }\end{array}$ & F-Hitung & F- tabel \\
\hline Perlakuan & 3 & 127.10 & 42.36 & 6.34 & 3,24 \\
\hline Error & 15 & 100.22 & 6.68 & - & - \\
\hline Total & 18 & 26.88 & - & - & - \\
\hline
\end{tabular}

Ket: Berdasarkan perhitungan analisis data keragaman jumlah daun tanaman cabai besar setelah 40 HSPT menunjukan $\mathrm{F}_{\text {hit }}>\mathrm{F}_{\text {tab }}$ dan di lanjutkan dengan uju BNT 5\% berbeda nyata atau tidak 
Perhitungan Beda Nyata Terkecil (BNT)

$$
\begin{aligned}
\text { BNT5\% } & =t .5 \%(\text { db.error }) x \sqrt{\frac{2 . K T E}{r}} \\
& =2,120 x \sqrt{\frac{2.100 .22}{4}} \\
& =2,120 x \sqrt{\frac{0,64}{4}} \\
& =2,120 x \sqrt{0,13} \\
& =2,120 x 0,36 \\
& =0,76 \\
B N T(0,05) & =0.76
\end{aligned}
$$

Tabel 9 Perlakuan Nilai Tengah

\begin{tabular}{|c|c|c|c|c|}
\hline \multirow{2}{*}{$\begin{array}{c}\text { Perlakuan dan } \\
\text { Nillai Tengah }\end{array}$} & \multicolumn{4}{|c|}{ Perlakuan dan Nilai Tengah } \\
\cline { 2 - 5 } & $\mathrm{L}_{0}$ & $\mathrm{~L}_{1}$ & $\mathrm{~L}_{2}$ & $\mathrm{~L}_{3}$ \\
\hline $\mathrm{L}_{0} 5,8$ & - & $1,4^{*}$ & $3,0^{*}$ & $3,8^{*}$ \\
$\mathrm{~L}_{1} 7,2$ & - & - & $1,0^{*}$ & $2,4^{*}$ \\
$\mathrm{~L}_{2} 8,0$ & - & - & - & $0,8^{*}$ \\
$\mathrm{~L}_{3} 9,6$ & - & - & - & - \\
\hline
\end{tabular}

Ket: Berdasarkan hasil uji BNT dan perhitungan nilai tengah maka dapat diketahui bahwa perlakuan $\mathrm{L}_{3}$ berbeda nyata dengan perlakuan $\mathrm{L}_{2}, \mathrm{~L}_{1}, \mathrm{~L}_{0}$. Perlakuan $\mathrm{L}_{2}$ berbeda nyata dengan $\mathrm{L}_{1}$, dan $\mathrm{L}_{0}$ dan perlakuan $\mathrm{L}_{1}$, berbeda nyata dengan $\mathrm{L}_{0}$

Sementara pertumbuhan panjang daun pada masing-masing perlakuan dari pra penelitian sampai tanaman berumur 40 hari setelah pindah tanam (HSPT) dengan rata-rata : perlakuan dengan menggunakan media tanam tanah $\left(\mathrm{A}_{0}\right)$ dengan rata-rata $4,17 \mathrm{~cm}$, perlakuan dengan menggunakan media tanam abu gosok $\left(\mathrm{A}_{1}\right)$ dengan rata-rata $6,37 \mathrm{~cm}$, perlakuan dengan menggunakan media tanam arang $\left(\mathrm{A}_{2}\right)$ dengan rata-rata $6,55 \mathrm{~cm}$, dan perlakuan dengan menggunakan media tanam pasir $\left(\mathrm{A}_{3}\right)$ dengan rata-rata $6,87 \mathrm{~cm}$, dimana $F_{\text {hitung }}>F_{\text {tabel }}$ $(6,34>3,24)$.

Perbedaan pertumbuhan tinggi tanaman, jumlah daun dan panjan daun pada tanaman cabai besar tersebut dipengaruhi oleh media tanam itu sendiri artinya diantara ketiga media tanam percobaan ini (abu gosok, pasir dan arang) ternyata yang paling bagus memberikan hasil dan respon pada pertumbuhan tinggi tanaman, jumlah daun dan panjang daun adalah media tanam pasir $\left(\mathrm{A}_{3}\right)$. Hal ini disebabkan karena media tanam hidroponik pasir bersifat steril, tidak mudah diserang penyakit. (Nichollis. R., 1993), menyatakan sejak tahun 30-an pasir merupakan pilihan yang sering dipakai karena sifatnya steril, dapat mempertahankan kelembaban yang baik dalam unit terbesar maupun terkecil. Disamping itu juga dengan menggunakan media tanam pasir memberi kemudahan dalam proses penyaluran nutrisi dan garam-garam mineral dengan cara yang paling sederhana adalah menaburkan garam-garam pupuk pada permukaan pasir lalu menuangkan air diatasnya, air akan melarutkan garam dan pasir akan menyerap air dan akar-akar akan menyerap zat-zat makanan tersebut (Nichollis, R., 1993). Sementara media tanam hidroponik abu gosok dan arang cenderung tidak mampu menahan kelembaban sehingga menyebabkan penyerapan akan garam mineral dan larutan nutrient tidak berlangsung dengan baik. 
(Nichollis, R., 1993), menyatakan penggunaan media tanam hidroponik abu gosok atau serbuk kayu mempunyai kecenderungan untuk menggumpal dan menempel pada akar dan batang tanaman sehingga nantinya akan menyebabkan akar dan batang tanaman membusuk yang paling akhirnya akan menyebabkan kematian pada tanaman tersebut

\section{KESIMPULAN}

Berdasarkan hasil penelitian, maka penulis dapat menarik kesimpulan bahwa Penggunaan media tanam hidroponik dapat mempengaruhi pertumbuhan cabai merah besar (Capsicum annum, varietas longum) baik itu pada tinggi tanaman, panjang daun dan jumlah daun. Media tanam hidroponik yang paling bagus adalah media tanam dengan pasir. Hal ini dapat dilihat pada pengukuran tiap-tiap parameter penelitian sebagai berikut : Tinggi tanaman paling tinggi dengan rata-rata 20,37 cm (40 HSPT), dengan jumlah daun yang paling banyak dengan rata-rata 9,25 lembar (40 HSPT), dan panjang daun yang paling panjang dengan rata-rata $6,87 \mathrm{~cm}$ (HSPT)

\section{DAFTAR PUSTAKA}

Azmin, N. (2015). Pertumbuhan Carica (Carica pubescens) Dengan Perlakuan Dosis Pupuk Fospor Dan Kalium Untuk Mendukung Keberhasilan Transplantasi Di Lereng Gunung Lawu. EL-VIVO, 3(1).

Hadiyanto, I. 1995. Bertanam Cabai,. Jakarta : Balai Pustaka

Iqbal A. (2008). Potensi Kompos dan Pupuk Kandang untuk Produksi Padi Organik. Jurnal Akta Agrosia. 5(1):13-18

Firmanto, Bagus H. (2011). Praktis Bertanam Bawang Merah secara Organik. Angkasa:Bandung. 74 hal

Marsono P, Sigit. (2001). Pupuk Akar: Jenis dan Aplikasinya. Jakarta. Penebar Swadaya.

Munawar A. (2011). Kesuburan tanah dan Nutrisi Tanaman. Bogor: IPB Press. 210 hal

Nichols, Richer. (1993). Hidroponik Tanaman Tanpa Tanah,. Semarang : Dahara Prizo

Setiadi, (2000). Bertanam Cabai. Edisi Refisi, Jakarta: Penebar Swadaya

Rahmawati, N., Nasir, M., \& Ariyansyah, A. (2019). Pengaruh Pemberian Kompos Enceng Gondok (Eichornia crassipes Solm) Terhadap laju Pertumbuhan Tanaman Cabai (Capsicum frutescens L.). ORYZA (Jurnal Pendidikan Biologi), 8(1), 21-25. Arikunto, S. 1989. Prosedur Penelitian Suatu Pendekatan Praktis, Jakarta : Bina Aksara

Susilawati, S., \& Ammar, M. (2019). Pengaruh Penggunaan Komposisi Media Tanam terhadap Pertumbuhan dan Hasil Tanaman Bawang Merah (Allium cepa L.). Seminar Nasional Lahan Suboptimal. 